\title{
Determinants of entrepreneurial intention among Sudanese university students
}

\author{
Mohamed Salih Yousif Ali ${ }^{a^{*}}$ and Emad Aldeen Essa Eshag Abou
}

${ }^{a}$ Faculty Member, Department of Business Administration, College of Science and Humanities Studies, Prince Sattam Bin Abdul Aziz University, Al-Aflaj, Saudi Arabia

${ }^{b}$ Department of Business Administration, College of Business Studies, Sudan University of Science and Technology, Khartoum, Sudan

\section{CH R O N I C L E A B S T RACT}

Article history:

Received: February 10, 2020

Received in revised format:

March 202020

Accepted: April 17, 2020

Available online:

April 17, 2020

Keywords:

Entrepreneurial determinants

Entrepreneurial intentions

University students

\begin{abstract}
This study examines the determinants of university students' entrepreneurship intentions. The effects of eleven factors of entrepreneurial intention were investigated, including personality, social, and societal factors. A convenience sampling method and 350 self-administered questionnaires were used for data collection from four Sudanese universities, obtaining a usable response rate of $84.6 \%$. Through Smart PLS, Structural Equation Modeling (SEM) was used for data analysis and relationship interpretation. The results showed that innovativeness and cultural valuation were positively and significantly associated with students' entrepreneurial intention. This suggests that the government and policymakers should encourage the development of entrepreneurship-fostering environments within universities. Future studies should increase the sample size to generalize the findings and validate new measures for the same study model, and explore a wider Sudanese entrepreneurial field scope.
\end{abstract}

\section{Introduction}

Over the years, understanding the factors that influence entrepreneurial intention has gained centrality within the research stream (Bird \& Jelinek, 1988; Boyd \& Vozikis, 1994; Krueger et al., 2000; Tolentino et al., 2014). However, until now, very few studies of this nature have been conducted in Sudan. Entrepreneurial intention refers to the intent to establish our own business (Krueger \& Brazeal, 1994). Aries et al. (2020) emphasized it as a suitable measure for entrepreneurship and it plays a key role in the conditions of an individual to become a nascent entrepreneur (Carsrud \& Brannback, 2011; Duonga, Nguyenb, Ngoa et al., 2020). Entrepreneurs play recognized roles in national economy development, especially in income generation, employment creation, skills development, provision of goods and services, and innovation (Bourne, 2011; Garo et al., 2015; Iakovleva et al., 2014; Duong et al., 2020; Olszewska, 2015; Urbano et al., 2018; Mitrovic Veljkovic et al., 2019).

According to Mitrovic Veljkovic et al. (2019), entrepreneurship intention is not just a single trait, but a combination of several traits that are influenced by different factors. Therefore, this serves as the starting point of this study. Moreover, given that despite being identified as a country that abounds with various natural resources, Sudan faces high graduate unemploymenta pressing matter that requires the consequential attention of the government and policymakers - it is even more imperative to understand the influence mechanism of entrepreneurial intentions among them. Thus, this study outlined the fallowing question:

To what extent do university students' personal, social, and societal factors have a significant relationship with their entrepreneurial intention?

* Corresponding author. Mobile: +966559684026 Office Phone +966115887456

E-mail address: my.ali@psua.edu.sa (M. S. Y. Ali)

(C) 2020 by the authors; licensee Growing Science, Canada doi: $10.5267 /$ j.msl.2020.4.023 
To answer this question, first, the above-mentioned factors were broken down to identify each one's components. Personal factors include optimism, risk-taking propensity, innovativeness, and competitiveness. Social factors include experiential activities, entrepreneurial family exposure, and entrepreneurial education. Societal factors comprise home country's economic and political conditions, home country's future economic and political conditions, and cultural valuation. Second, the study's sampling criteria was set. According to Kautonen, Van Gelderen, and Fink (2015), the career-related behaviors and choices of university graduates are linked to their entrepreneurial intent. Therefore, the criteria were set to include only students in their final and semi-final years of study since they were more likely to have started thinking much about their future work and careers. This study contributes to economic development, particularly in solving graduates' unemployment. The rest of this study's sections are as follows. After the definitions of terms used, we present the literature review in section 2 . Section 3 discusses the methodology employed for this study, followed by data analysis in section 4 , the discussion of the research results in section 5, and finally the conclusions in section 6.

\section{The definitions of terms}

Optimism refers to the ability and predilection to think carefully, creatively, and recognize opportunities for new practicable ideas, and finding new markets to introduce them (Chen, 2007; Gupta et al., 2004).

Risk-taking propensity refers to a tendency to take or avoid risks.

Competitiveness in general refers to the desire or spirit to be the winner or excel in interpersonal situations (Helmreich \& Spence, 1978; Ozaralli \& Rivenburgh, 2016).

Innovativeness is the creative thinking process of transforming thoughts and expertise into novel and valuable ideas (Sutha \& Sankar, 2016).

Successful entrepreneurial family refers to students' perceived level of success of their entrepreneurial parents (Ozaralli \& Rivenburgh, 2016).

Entrepreneurial family exposure refers to the existence of a direct entrepreneurial family background and role models that can affect inclinations towards entrepreneurial conducts and create desire and conviction to become an entrepreneur (Carr \& Sequeira, 2007).

Entrepreneurial education refers to educational curriculums that develop and enhance entrepreneurial creativity, realization, knowledge, and expertise to run a successful entrepreneurial venture (Bechard \& Toulouse, 1998; De Jorge-Moreno et al., 2012; Lee, Chang, \& Lim, 2005; Rauch \& Frese, 2000; Sutha \& Sankar, 2016).

Experiential activities refer to experiences or the flow of experiences that promotes creative thinking and innovative idea generation that can contribute to cognitive variety and new venture development (Seelig, 2012; Zaki, 2012). This may include entrepreneurship experience obtained from training activities, assisting friends in their businesses, and administering one's own business (Darmantoa \& Pujiartia, 2020).

Cultural valuations refer to the entrepreneurial image in the society that enables and boosts positive entrepreneurial activity valuations using social approaches (Güney et al., 2006).

Economic and political conditions of the home country refer to the existing economic and political infrastructures of the home country that influence the prospective entrepreneur's intention and market-oriented behaviors (Aldrich \& Wiedenmayer, 1993).

Future economic and political condition refers to the anticipated future of economic and political conditions that affects investment projects and individuals' income, in turn, influencing entrepreneurial entry decisions.

\section{Literature review}

2.1 Personality factors as entrepreneurial determinants: optimism, innovativeness, risk-taking propensity, and competitiveness

Existing research findings show that personal characteristics are important factors that influence attitudes towards entrepreneurship (Baron \& Markman, 2003; Baum \& Locke, 2004; Collins et al., 2004). Authors have indicated the need for optimism among entrepreneurs (e.g., Hmieleski \& Baron, 2006; Lovallo \& Kahneman, 2003). Similarly, Janssen et al. (2013) found that optimistic students have more entrepreneurial tendencies and have stronger intentions than others to follow their desired entrepreneurial careers. Further, Knaup (2005) considered that the creation of a new venture is a complicated process and that more than half of those who establish new ventures at any given time eventually fail. Therefore, starting a new venture demands positivity on the side of the entrepreneur (Ozaralli \& Rivenburgh, 2016). Thus, the following hypothesis is proposed:

Hypothesis 1 (H1). The student's optimism will significantly affect his/her entrepreneurial intention. 
As mentioned before, innovativeness refers to the entrepreneurs' creative thinking ability and an inclination to recognize opportunities for producing and introducing novel practical ideas, and creating new product markets for them (Chen, 2007; Gupta et al., 2004). Some researchers provided evidence regarding the significant positive relationship between innovativeness and entrepreneurial intent (Gürol \& Atsan, 2006; Räty et al., 2019). A person with higher levels of innovative characteristics than his/her non-entrepreneurial counterparts is more likely to venture into a business (Gürol \& Atsan, 2006). Innovation, as a fundamental motive for novel ventures, has affected venture performance significantly (Hisrich, Peters, \& Shepard, 2008). Therefore, the linkage between students' innovativeness and entrepreneurial intentions is hypothesized as follows:

Hypothesis 2 (H2). The student's innovativeness will significantly affect his/her entrepreneurial intention.

Risk-taking propensity signals the ability to overcome the difficulties, uncertainties, and unpredictable circumstances that may follow a decision and acclimate to them successfully (Lüthje \& Franke, 2003; Macko \& Tyszka, 2009). Laudano et al., (2019) found that risk-taking propensity is an important antecedent of entrepreneurial attitudes in both Italy and Albania samples. Individuals who naturally have higher risk tolerance have higher entrepreneurial intentions (Dheer et al., 2019; Hmieleski \& Corbett, 2006). One's readiness for risk-taking plays a substantial role in achieving business success (Trung et al., 2020). Risk propensity is the best indicator of entrepreneurial intentions compared to other entrepreneurial traits (Zhao, Seibert, \& Lumpkin, 2010). A student's risk-taking propensity leads to greater levels of entrepreneurial intentions compared to students with no such inclination (Gürol \& Atsan, 2006; Ozaralli \& Rivenburgh, 2016). At all times, entrepreneurship is associated with risk-taking (Sutha \& Sankar, 2016). Therefore, the linkage between students' risk-taking propensities and entrepreneurial intentions is hypothesized as follows:

Hypothesis 3 (H3). The student's risk-taking propensity will significantly affect his/her entrepreneurial intention.

Schumpeter (1947) underlined competitiveness as a great motive to take part in entrepreneurial activities. Further, many authors conceptualize competitiveness as a personal characteristic that widely influences work-related behaviors and interpersonal relationships (Griffin-Pierson, 1990; Houston et al., 2002). Additionally, Rauch and Frese (2000) found that competitiveness is connected to achievement needs that related positively with venture performance. Thus, the following hypothesis is proposed:

Hypothesis 4 (H4). The student's competitiveness will significantly affect his/her entrepreneurial intention.

2.2 Social factors ass entrepreneurial determinants: experiential activities, entrepreneurial family exposure, and entrepreneurship education

Previous entrepreneurial experience acts as a fundamental factor of entrepreneurial intention (Darmantoa \& Pujiartia, 2020). The entrepreneur's previous experience in managing or starting a business enables him/her to learn further about its processes and improves their probability to start a (or another) business in future (Elston \& Weidinger, 2019). Experience can also be gained from others by reading their books, travelling, watching their movies, and trying their foods. Thus, the following hypothesis is proposed:

Hypothesis 5 (H5). The student's entrepreneurial experience will significantly affect his/her entrepreneurial intention.

Many researchers (e.g., Franke \& Lüthje, 2004; De Jorge-Moreno et al., 2012; Ozaralli \& Rivenburgh, 2016; Lee et al. 2005; emphasized the positive role of entrepreneurial education in people's future entrepreneurial spirit. Further, education also plays a remarkable role in developing primary knowledge, skills, and competence as set of capabilities essential to entrepreneurship (Thanha et al., 2020). Entrepreneurship education is specified as the most pivotal factor that would support youngsters to embrace and develop their entrepreneurial approach (Gorman, Hanlon, \& King, 1997; Walstad \& Kourilsky, 1998). Building on the above discussions, the following hypothesis is proposed:

Hypothesis 6 (H6). The student's entrepreneurial education will significantly affect his/her entrepreneurial intention.

Many authors provide evidence that the individual's family background can significantly affect their entrepreneurial intention by molding their attitudes (Gunnarsson, 2000; Garo et al., 2015; Kirkwood, 2007; Mueller, 2006).

Similarly, Shapero (1982) concluded that fathers, mothers, and peers play the biggest role in entrepreneurial behaviors and the attractiveness of establishing a business. Recent literature reviews focusing on students and their family entrepreneurial background showed a strong positive relationship between a family's entrepreneurial background and entrepreneurial intent (Garo et al., 2015; Mitrovic Veljkovic et al., 2019). Therefore, the relationship between family entrepreneurial exposure and entrepreneurial intention is hypothesized as follows:

Hypothesis 7 (H7). The student's family entrepreneurial exposure will significantly affect his/her entrepreneurial intention.

Regarding the students' successful entrepreneurial family, Ozaralli and Rivenburgh (2016) found that exposure to a successful entrepreneurial family had a significant contribution to the entrepreneurial intent of both US and Turkish student samples. Students who come from successful entrepreneurial families have higher tendencies to establish their own businesses (Liñán, Rodriguez-Cohard, \& Rueda-Cantuche, 2005; Mueller, 2006; Ozaralli \& Rivenburgh, 2016). In addition, Mitrovic Veljkovic 
et al. (2019) found that Hungarian business-owning families significantly influenced their students to become entrepreneurs. According to Fairlie and Robb (2005) and Mcelwee (2003), family history reveals that children of entrepreneurial parents have a bigger propensity to select self-employment and develop their entrepreneurial potential. Further, some entrepreneurs admitted that they got their skills, confidence, values, financial help, and marketing aid from their family's business (Altınay, 2008; Dunn \& Eakin, 2000). Thus, the following hypothesis is proposed:

Hypothesis 8 (H8). The student's successful entrepreneurial family will significantly affect his/her entrepreneurial intention.

2.3 Societal factors as entrepreneurial determinants: Present economic and political conditions of the home country, Future economic and political conditions of the home country, and Cultural valuation

Entrepreneurial intention is connected to economic, political, and cultural mechanisms (Gelard \& Saleh, 2011; Kot, Meyer, \& Broniszewska, 2016). Ozaralli and Rivenburgh (2016) found that the present and future economic and political conditions of one's home country could favorably or unfavorably influence their intentions to start their own businesses. Perceived entrepreneurial opportunities are positively associated with economic reforms and new venture entry decisions (Elton \& Weidinger, 2019). Decades ago, Dunhof (1949) found that at the initial stage of economic development, entrepreneurs had low levels of initiative and drive, but as economic development proceeded, they became more innovative and enthusiastic. Additionally, numerous factors are found to transfer or motivate entrepreneurial intentions while others become obstacles that kill it - these are business environmental factors and personal circumstances (Duong et al., 2020; Trung et al., 2020). For example, these may be bureaucratic procedures, corruption, intellectual property rights, business cycle fluctuations, top inflation rates, and high unemployment. Therefore, the following hypotheses are proposed:

Hypothesis 9 (H9). The student's home country's economic and political condition will significantly affect his/her entrepreneurial intention.

Hypothesis 10 (H10). The student's home country's future economic and political condition will significantly affect his/her entrepreneurial intention.

Gasse and Tremblay (2011) suggested that a country's cultural environment could favor or discourage a student's entrepreneurial career decisions. Guerrero, Rialp, and Urbano (2008) deduced that positive cultural stands toward entrepreneurship and the status given to entrepreneurs played influential roles in students' intentions to set their own businesses. Thus, culture plays a strong part in motivating individuals, groups, and communities to accept certain prevalent behaviors in other societies (Thomas \& Mueller, 2000). Therefore, the following hypothesis is proposed:

Hypothesis 11 (H11). The student's home country's entrepreneurial culture will significantly affect his/her entrepreneurial intention.

\section{Methodology}

Given the study's aim to increase the understanding of factors that influence university students' entrepreneurial intentions, a questionnaire-based survey that encompasses a diversity of multi-item measures was designed for both public and private university students. The study covered three public universities (Sudan University of Sciences and Technology, University of Khartoum, and Al-Neelain University) and one private university. Data collection was carried out late in the first term of the 2018-2019 academic year using random convenience sampling. The study sampled only students that were in their final and semi-final semesters, just before graduating from the university. To insure the participants' confidence and willingness to fill the questionnaire, a short letter explaining the purpose of the survey was attached to the questionnaire. This self-administrated questionnaire was initially written in English, then translated to Arabic, and translated back to English after data collection. This process was completed by two university translation lecturers. Twenty-five final-year students of Sudan University of Sciences and Technology (SUST) pre-tested and refined the questionnaire. After the scale measures satisfied the reliabilities, the final questionnaire was distributed. The questionnaire contained two sections. The first section was about participants' personal profiles, while the second section was on the study's main variables. All the questionnaire items were based on a five-point Likert scale. Statistical techniques including descriptive statistics, common method bias tests, exploratory factor analysis (EFA), reliability tests, and smartPLS, were applied for data analysis.

\subsection{Sample and data collection}

For primary data collection, the study used convenience sampling. This type of sampling involves using easy-to-reach or conveniently placed participants among different universities. Of the 550 questionnaires distributed, 296 of them were collected, all of which were usable, thus, a response rate of $84.6 \%$. Table 1 illustrates the personal profiles of participants. The study's male participants accounted for $59 \%$, while the females accounted for $41 \%$. Those between the ages of 22 and 27 years accounted for $61.1 \%$ of the sample; $27 \%$ were less than 22 years; $9.5 \%$ were between 27 and 32 years, and $2.4 \%$ were more than 32 years. Of the sample, 50\% were from SUST, 28\% from University of Khartoum, 13.5\% from Al-Neelain University, and $8.5 \%$ from the private university. 
Table 1

Personal profile of the study's participants

\begin{tabular}{|c|c|c|c|}
\hline \multicolumn{2}{|c|}{ Variable } & Frequency & Percent \\
\hline \multirow[t]{2}{*}{ Gender } & Male & 174 & 59.0 \\
\hline & Female & 122 & 41.0 \\
\hline \multirow{4}{*}{ Age } & Less than 22 & 80 & 27.0 \\
\hline & From 22 to 27 & 181 & 61.1 \\
\hline & From 27 to 32 & 28 & 9.5 \\
\hline & More than 32 & 7 & 2.4 \\
\hline \multirow{4}{*}{ University } & SUST & 148 & 50.0 \\
\hline & $\mathrm{U}$ of $\mathrm{K}$ & 83 & 28.0 \\
\hline & Al-Neelain & 40 & 13.5 \\
\hline & Private University & 25 & 8.5 \\
\hline Total & & 296 & $100 \%$ \\
\hline
\end{tabular}

\subsection{Measures}

This study applied measures conducted from well-examined existing scales provided by previous literature, some rewording and modifications were made to suit the Sudan student context. It is worth mentioning that all participants' responses were assessed using a five-point Likert scale, with response scores ranging between 1 (strongly disagree) and 5 (strongly agree). Personality factors were assessed as follows. The measure for risk-taking propensity, based on attitude toward taking risks, was borrowed from Gomez-Mejia and Balkin (1989), Scheier and Carver (1992), and Norton and Moore (2006), involving a five-item Likert-type scale. Items included were "I am willing to take higher risks for higher returns" and "I never fear moving into a new undertaking I know nothing about." The innovativeness measure, adopted from scales used by Scheier and Carver (1992) and Thomas and Mueller (2000), contained five items. These items encompassed "I like to experiment with various ways of doing the same thing" and "I am able to get around difficulties through strokes of ingenuity and resourcefulness." Optimism was measured by four positive items from the scale by Scheier and Carver (1992). The items included "I always look on the bright side of things" and "I feel my performance will improve next year." The competitiveness measure was borrowed from Lynn's (1991) scale, which consisted of five items including "I enjoy working in situations involving competition with others" and "I usually get what I want, because I worked hard for it." Social factors were assessed as follows. The experiential activities measure was borrowed from studies of Amabile and Pillemer (2012) and Page (2007), which included five items such as "I always read books by foreign authors", "I always watch foreign movies," and "I always meet new people from different cultures." The entrepreneurship education measure was derived from a widely used measure by studies of Vesper (1983), Kolveried (1996), Bechard and Toulouse (1998), and Gorman et al. (1997). This measure uses a four-item Likert-type scale. The items included "I am interested in receiving entrepreneurial training as part of my university education" and "I hope to have more business-related education before I start a new business." Entrepreneurial family exposure was assessed based on the works of Chen, Greene, and Crick (1998) and Ozaralli and Rivenburgh (2016), this four item measure included statements such as "I have a family member who started a business in the last five years" and "I have an immediate family member who started a business." Similarly, successful entrepreneurial family was assessed through a four-item measure derived from the scales by Chen et al. (1998) and Ozaralli and Rivenburgh (2016), which included items like "I have a family member who was successful as an entrepreneur" and "I have a family member who will be a successful entrepreneur in the next five years." Societal factors were measured as follows. Cultural valuation was measured through a scale developed by Liñán (2008). This five-item Likert-type scale comprised items like "The culture in my country is highly favorable towards entrepreneurial activities" and "The entrepreneur's role in the economy is generally undervalued in my country." Present and future economic and political conditions of home countries were measured through scales borrowed from Ozaralli and Rivenburgh (2016), which had four items for each aspect of the variable. These items included "I think that the current economic conditions of my home country are better for starting a new business" and "I think that the current political conditions of my home country are better for starting a new business." For future economic and political conditions, items included "I think that the economic conditions of my home country in the coming five to 10 years will be better" and "I think that the political conditions of my home country in the coming five to 10 years will be better."

Lastly, entrepreneurial intention was assessed using scales by Liñán and Chen (2009) and Thompson (2009), which included six items. Example items are "I plan to start a new business within five years of completing my studies" and "It is one of my career's aims to become an entrepreneur."

\section{Data analysis}

\subsection{Exploratory factor analysis (EFA) and confirmatory factor analysis (CFA)}

The study employed EFA to test 55 items of the questionnaire that reflected twelve variables of the model. As a result, ten items that did not satisfy the factor measuring terms were deleted from the analyses process. In addition, on the final run, the items tested measuring loading ranged between .640 and .948 , and the average variance extracted (AVE) was above the recommended level of .5 for the remaining items. The $R^{2}=.526$, adjusted $R^{2}=.438$, and the explained cumulative variance was $000 \%$ of the study data. 
On the other hand, CFA, using Smart PLS 3.0, was conducted to check the model fit and the measurements scores are shown on Figure 1. To achieve the covariance between the questionnaire items, nine items were dropped from the 55 model items, resulting in an acceptable model fit. The fit indices detected that the standardized root mean square residual (SRMR) is .095, Chi-square is 1.176 .453 , d_ULS is 5.961, NFI is .471, P Close is $>0.05$, and the model RMS Theta is .195. The above indices altogether displayed a desirable fit.

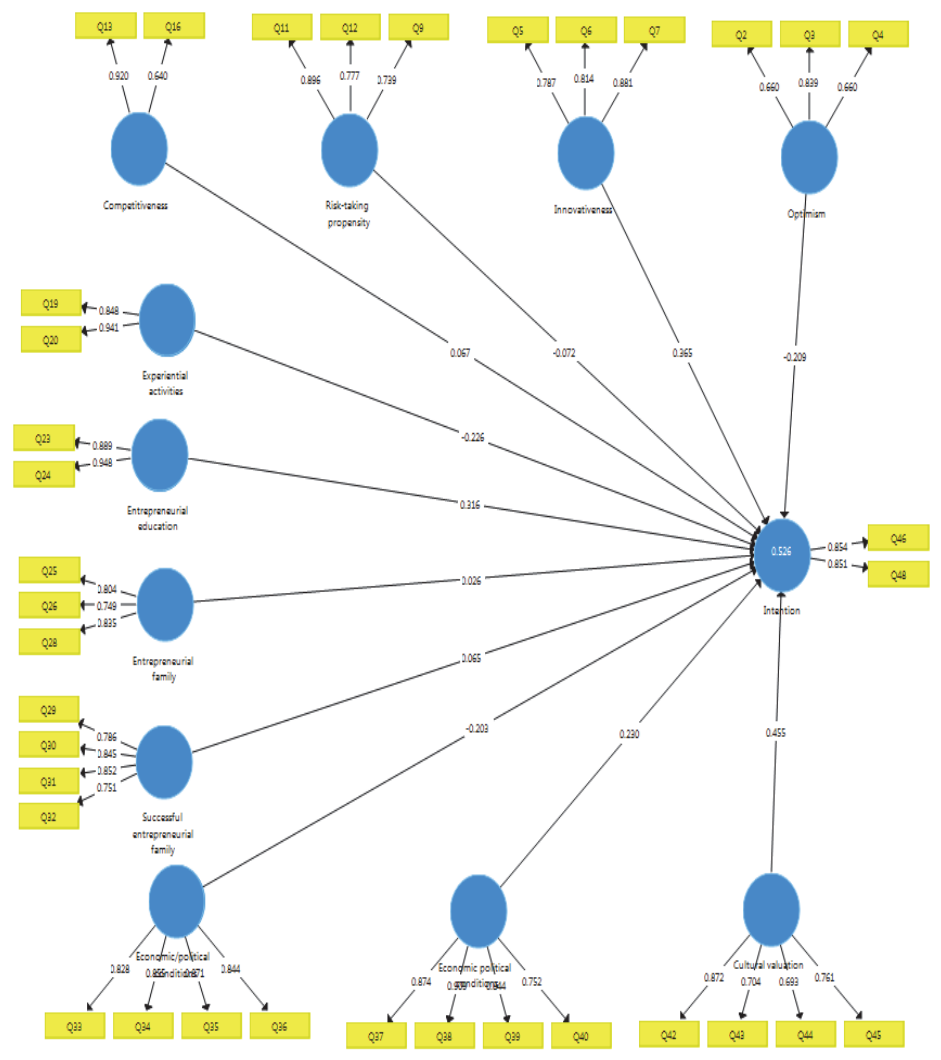

Fig. 1. The study model fit

\subsection{Reliability and validity}

This section reports on the reliability indicators, convergent validity, and discriminatory validity methods that were used to test the constructs' goodness of measures.

Table 2

Standardized Regression Weight

\begin{tabular}{lccc}
\hline & Cronbach's Alpha & rho_A & Composite Reliability \\
\hline Competitiveness & 0.446 & 0.447 & 0.783 \\
Cultural valuation & 0.757 & 0.779 & 0.846 \\
Future Economic political conditions & 0.867 & 0.878 & 0.910 \\
Economic/political conditions & 0.877 & 0.877 & 0.916 \\
Entrepreneurial education & 0.822 & 0.900 & 0.916 \\
Entrepreneurial family & 0.718 & 0.718 & 0.842 \\
Experiential activities & 0.764 & 0.780 & 0.894 \\
Innovativeness & 0.772 & 0.779 & 0.869 \\
Intention & 0.623 & 0.623 & 0.841 \\
Optimism & 0.578 & 0.577 & 0.780 \\
Risk-taking propensity & 0.743 & 0.744 & 0.853 \\
Successful entrepreneurial family & 0.826 & 0.828 & 0.832 \\
\hline
\end{tabular}

Table 2 reveals the composite reliability (CR) scores, ranging between .780 and .916 , confirming acceptable reliability (Bagozzi \& Yi, 1988; Hair et al., 2010). Further, the Cronbach's Alpha value for competitiveness is less than 0.5 (questionable remark), but at the same time, in the Composite Reliability, it is equal to 0.783, which is greater than the suggested score 0.7 . However, all the other constructs satisfied the recommended values. Thus, these results show that the study's constructs meet satisfactory internal consistency reliability levels. For the convergent validity test, the study used the average variance extracted (AVE) method. Table 2 reveals all the AVE values that exceed the recommended score of 0.5 , which shows that the study's model meets acceptable convergent validity levels. In order to confirm the discriminant validity, this study used the heterotrait-monotrait (HTMT) ratio of correlations test by Henseler et al. (2014) to assess whether the measure performs well 
on both types of SEM (Voorhees, Brady, Calantone, \& Ramirez, 2015). Table 3 shows the discriminant validity scores, which reflect that the measures meet the HTMT criterion. Based on the above findings, this study's measurement model was concluded to be valid and reliable in the terms of the observed scores' internal consistency, and convergent and discriminant validities before the hypothesis's tests were done.

Table 3

Discriminant validity

\begin{tabular}{|c|c|c|c|c|c|c|c|c|c|c|c|}
\hline Cultural valuation & 0.416 & & & & & & & & & & \\
\hline Economic political conditions & 0.842 & 0.388 & & & & & & & & & \\
\hline Economic/political conditions & 0.643 & 0.472 & 0.844 & & & & & & & & \\
\hline Entrepreneurial education & 0.788 & 0.416 & 0.686 & 0.635 & & & & & & & \\
\hline Entrepreneurial family & 0.602 & 0.275 & 0.683 & 0.658 & 0.692 & & & & & & \\
\hline Experiential activities & 0.442 & 0.271 & 0.675 & 0.511 & 0.518 & 0.808 & & & & & \\
\hline Innovativeness & 0.797 & 0.363 & 0.545 & 0.623 & 0.475 & 0.393 & 0.526 & & & & \\
\hline Intention & 0.622 & 0.815 & 0.567 & 0.463 & 0.612 & 0.451 & 0.366 & 0.629 & & & \\
\hline Optimism & 0.758 & 0.414 & 0.559 & 0.515 & 0.455 & 0.453 & 0.463 & 0.775 & 0.307 & & \\
\hline Risk-taking propensity & 0.544 & 0.525 & 0.524 & 0.672 & 0.752 & 0.475 & 0.610 & 0.589 & 0.460 & 0.718 & \\
\hline Successful entrepreneurial family & 0.782 & 0.563 & 0.888 & 0.815 & 0.816 & 0.718 & 0.716 & 0.397 & 0.605 & 0.395 & 0.725 \\
\hline
\end{tabular}

\subsection{Common method bias}

To evaluate the overall quality of the study's framework measurements, Kock and Lynn (2012), Kock and Gaskins (2014), and Kock (2015) proposed a full collinearity test that comprehensively processes simultaneous evaluations of vertical and lateral collinearity, using WarpPLS software, and variance inflation factors (VIFs) for latent variables. Table 4 displays the outputs of VIFs that were obtained from the above test. To that end, all variables, except one (Q38), showed a VIF less than 3.3. Therefore, the study's measurements can be considered safe from common method bias.

Table 4

Full collinearity of VIFs outer values

\begin{tabular}{|c|c|c|c|c|c|}
\hline Item & VIF & Items & VIF & Items & VIF \\
\hline Q11 & 1.748 & Q29 & 1.640 & Q4 & 1.168 \\
\hline Q12 & 1.764 & Q3 & 1.153 & Q40 & 1.703 \\
\hline Q13 & 1.090 & Q30 & 2.114 & Q42 & 1.801 \\
\hline Q16 & 1.090 & Q31 & 2.241 & Q43 & 1.384 \\
\hline Q19 & 1.617 & Q32 & 1.978 & Q44 & 1.336 \\
\hline Q2 & 1.254 & Q33 & 2.351 & Q45 & 1.538 \\
\hline Q20 & 1.617 & Q34 & 2.801 & Q46 & 1.257 \\
\hline Q23 & 1.948 & Q35 & 3.041 & Q48 & 1.257 \\
\hline Q24 & 1.948 & Q36 & 1.639 & Q5 & 1.313 \\
\hline Q25 & 1.349 & Q37 & 3.055 & Q6 & 2.052 \\
\hline Q26 & 1.440 & Q38 & 3.379 & Q7 & 2.259 \\
\hline Q28 & 1.445 & Q39 & 2.186 & Q9 & 1.272 \\
\hline
\end{tabular}

\subsection{Structural model and hypotheses testing}

The study's overall model fit was evaluated through SEM in accordance with procedures proposed by Bagozzi and Yi (1991) and Hair et al. (2010). The study's R-square value is equal to 0.78 , showing that the variance explains 0.78 of entrepreneurial intention. The structural model of the study appears to have the same values of the model fit revealed in Table 5 .

Table 5

Study paths' coefficients for hypothesis testing

\begin{tabular}{|c|c|c|c|c|c|}
\hline Paths & $\begin{array}{c}\text { Original } \\
\text { Sample }(\mathrm{O})\end{array}$ & $\begin{array}{c}\text { Sample } \\
\text { Mean (M) }\end{array}$ & $\begin{array}{c}\text { Standard } \\
\text { Deviation } \\
\text { (STDEV) }\end{array}$ & $\begin{array}{l}\text { T Statistics } \\
(|\mathrm{O} / \mathrm{STDEV}|)\end{array}$ & $\begin{array}{c}\mathrm{P} \\
\text { Values }\end{array}$ \\
\hline Competitiveness $\rightarrow$ Intention & 0.067 & 0.028 & 0.157 & 0.43 & 0.667 \\
\hline Cultural valuation $\rightarrow$ Intention & 0.455 & 0.464 & 0.107 & 4.243 & 0.000 \\
\hline Economic political conditions $\rightarrow$ Intention & 0.23 & 0.185 & 0.249 & 0.924 & 0.356 \\
\hline Future economic/political conditions $\rightarrow$ Intention & -0.203 & -0.181 & 0.185 & 1.098 & 0.273 \\
\hline Entrepreneurial education $\rightarrow$ Intention & 0.316 & 0.311 & 0.219 & 1.441 & 0.150 \\
\hline Entrepreneurial family $\rightarrow$ Intention & 0.026 & 0.009 & 0.15 & 0.171 & 0.865 \\
\hline Experiential activities $\rightarrow$ Intention & -0.226 & -0.192 & 0.161 & 1.41 & 0.159 \\
\hline Innovativeness $\rightarrow$ Intention & 0.365 & 0.34 & 0.113 & 3.227 & 0.001 \\
\hline Optimism $\rightarrow$ Intention & -0.209 & -0.115 & 0.154 & 1.364 & 0.173 \\
\hline Risk-taking propensity $\rightarrow$ Intention & -0.072 & -0.1 & 0.158 & 0.456 & 0.649 \\
\hline Successful entrepreneurial family $\rightarrow$ Intention & 0.065 & 0.112 & 0.228 & 0.286 & 0.775 \\
\hline
\end{tabular}


Table 5 depicts the main information concerning the hypothesized relationships paths. Under P-value for statistical significance, two paths, Cultural valuation -> Intention and Innovativeness -> Intention, show significantly positive influence (pvalue $<0.05)$, supporting their respective hypothesis. The other nine paths observed statistically insignificant influences; therefore, their hypothesized relationships were not supported.

\section{Discussion}

The study shows that the sampled Sudanese university students had low entrepreneurial intention (based on a 5-point Likert scale) during the last three years. Only two factors of the study, innovativeness and cultural valuation, agreed with the study's original conceptualization. These finding concur with prior studies, which emphasized that, innovation as a universal trait leads to high levels of entrepreneurial intentions (Ozaralli \& Rivenburgh, 2016). Students are able to perceive business opportunities and believe that they can acquire the ability to succeed in unusual situations. Further, a student's culture is highly favorable to entrepreneurial activities and plays a valuable role in the economy. This result aligns with Ozaralli and Rivenburgh's (2016) finding that United States and Turkish students' homes countries' cultural valuations influenced their entrepreneurial intentions.

On the other hand, this study reveals that the other factors have insignificant relationships with entrepreneurial intention. The justification for this may be as follows. First are the students' perceived societal barriers, including unfavorable present economic and political conditions of their home countries, expectations of unfavorable future conditions, and an increase in poverty and unemployment rates in the capital of Sudan. Fluctuations in societal conditions lead to economic and political instability, high market fluctuations, and high unemployment rates. Likewise, these findings concurred with those of previous researches such as findings that Turkey's unfavorable present and future political and economic situations discourage Turkish students and cause them to make unfavorable assessments about their entrepreneurial intentions (Ozaralli \& Rivenburgh, 2016). In support of this, it becomes evident that financial constraints are the key barriers to entrepreneurship (Finnerty \& Krzystofik, 1985; Thanha et al., 2020).

Second are the student's social barriers, including lack of experiential activities, lack of entrepreneurial family exposure, and lack of entrepreneurship education. These findings agree with Gubik and Farkas's (2016) research results that entrepreneurial education significantly influences most students to become entrepreneurs. The absence of successful entrepreneurial families that the students could inherit or from which they could acquire certain needed skills, experience, and confidence might be an obstacle to entrepreneurship intention. This finding agrees with the arguments of Garo et al. (2015) and Mitrovic Veljkovic et al. (2019) that students or young people who lack entrepreneurial role models in their families lack entrepreneurial potential. Further, individuals that do not belong to entrepreneurial families tend to lack support — an important element for business success - such as receiving inspiration and funding for their potential entrepreneurial activities (Akehurst, Simarro, \& MasTur, 2012; Dunn \& Eakin, 2000; Olszewska, 2015). The study also found that few students wished to pursue entrepreneurial careers immediately after leaving university. This result is similar to that of Akava (2016), who found that a great majority $(69 \%)$ of university-educated young people indicated that they would prefer to work as employees compared to the $8 \%$ that aspired to becoming entrepreneurs. These findings imply that these students have negative attitudes toward an entrepreneurial career, likely due to the current difficulties of creating new businesses, the lack of opportunities to experience foreign cultures, and their country's conditions. In contrast, those students who have positive attitudes toward an entrepreneurial career and high self-confidence possess more favorable intentions and abilities to create their own businesses (Peterman and Kennedy 2003).

Third, there are personality barriers, including pessimism, lack of competitiveness, and fear of failure. The students felt negatively about the economic conditions of their country and did not expect any improvement, adversely affecting their entrepreneurship intentions. High uncertainty about the external environment decreases the ability to plan for new projects, as well as the willingness to take risks. This outcome is in line with some authors' findings that suggest that optimism among educational institutions, investors, media, and communities today is required to support future entrepreneurship (Khan, Sharma, \& Thoudam, 2019). The fear of taking risks has negative effects on entrepreneurial intention (Giacomin et al., 2011). The findings of this study also emphasized competitiveness as a personality trait that affects entrepreneurial intention. Finally, entrepreneurship is a planned behavior; that is, an intentional process that requires previous planning (Bird \& Jelinek, 1988; Krueger \& Carsrud, 1993; Krueger et al., 2000).

\subsection{Limitations and future studies}

This study suffered a few limitations, especially since the data was collected from only four universities. Firstly, it has utilized the questionnaire survey as the preliminary quantitative data collection technique. Future studies should apply qualitative and/or mixed techniques. Secondly, the study measured the factors of entrepreneurial intention using variables adopted from previous researches. Further studies should employ other variables related to personality, social, and social factors to measure students' entrepreneurial intention. Thirdly, the study only focused on testing the direct effects of three types of factors. Future studies may extend this study model by inserting moderating and mediating variables to reach positive significant relationships. Finally, the small number of study participants researched is a considerable limitation as well. Future studies should remedy this restriction by widening the sample size. 


\section{Conclusion and implication}

The study has provided interesting insight on Sudanese entrepreneurship and fetches advantageous recommendations to government, policymakers, and universities. This study outlines both significant and insignificant factors of Sudanese graduates' entrepreneurship intentions and suggests the need for the development of personal and professional characteristics, as well as implications about external conditions. For instance, students' low intentions to start businesses within five years of completing their studies indicates a need to improve Sudan's attractiveness in terms of entrepreneurship, especially since students perceive the difficulty in starting businesses in the current economic and political conditions.

To increase students' willingness and abilities to start businesses, the government and policymakers should focus on cultivating innovativeness and cultural valuations towards entrepreneurial activities and create an environment that will spread this positive outlook on entrepreneurship. Additionally, they should make further efforts in funding business incubators and reconsidering the current microfinance programs being offered to graduates. At the same time, universities should assign more attention to developing the entrepreneurial ecosystem within their institutions, introducing or increasing training programs or classes that cover different aspects of entrepreneurship, and holding seminars that present examples of successful students or graduate led businesses from different countries. Doing these will provide the students with the required competencies, knowledge, and skills that facilitate business creation and management. Students would also learn how to cope better with entrepreneurial challenges and barriers that are common in new ventures and heighten their inclinations towards entrepreneurship. Lastly, communities and students' families should be encouraged to provide positive support.

\section{References}

Akava (2016). Survey on high-educated young people want stability from their working life. available at: www.akavalainen.fi/akavalainen/arjessa/tyoelamassa/mita_korkeakoulutetut_nuoret_haluavat_tulevaisuuden_ tyoelamalta (accessed 18 March 2019).

Akehurst, G., Simarro, E., \& Mas-Tur, A. (2012). Women entrepreneurship in small service firms: Motivations, barriers and performance. The Service Industries Journal, 32(15), 2489-2505.

Aldrich, H. E. \& Wiedenmayer, G. (1993). From traits to rates: An ecological perspective on organizational findings. In J. A. Katz, \& R. H. Brockhaus (eds.). Advances in Entrepreneurship from emergence, and growth (145-195) Greenwich, CT: JAI Press.

Altınay, L. (2008). The relationship between an entrepreneur's culture and the entrepreneurial behavior of the firm. Journal of Small Business and Enterprise Development, 15(1), 111-129.

Amabile, T. M., \& Pillemer, J. (2012). Perspectives on the social psychology of creativity. The Journal of Creative Behavior, $46,3-15$.

Aries, A., Vional, V., Saraswati, L., Wijaya, L., \& Ikhsan, R. (2020). Gamification in learning process and its impact on entrepreneurial intention. Management Science Letters, 10(4), 763-768.

Bagozzi, R. P., \& Yi, Y. (1991). Multitrait-multimethod matrices in consumer research. Journal of Consumer Research, 17(4), 426-439. https://doi.org/10.1086/208568

Bagozzi, R.P., * Yi, Y. (1988). On the evaluation of structural equation models. Journal of the Academy of Marketing Science, 16(1), 74-94.

Baron, R. A., \& Markman, G. D. (2003). Beyond social capital: The role of entrepreneurs' social competence in their financial success. Journal of Business Venturing, 18(1), 41-60.

Baum, J. R., \& Locke, E. A. (2004). The relationship of entrepreneurial traits, skill, and motivation to subsequent venture growth. Journal of Applied Psychology, 89(4), 587-598.

Bechard, J. P., \& Toulouse, J. M. (1998). Validation of a didactic model for the analysis of training objectives in entrepreneurship. Journal of Business Venturing, 13(4), 317-332.

Bird, B., \& Jelinek, M. (1988). The operation of entrepreneurial intentions. Entrepreneurship Theory and Practice, 13(2), 2129.

Bourne, L. (2011). Advising upwards: Managing the perceptions and expectations of senior management stakeholders. Management Decision, 49, 1001-1023.

Boyd, N. G., \& Vozikis, G. S. (1994). The influence of self-efficacy on the development of entrepreneurial intentions and actions. Entrepreneurial Theory and Practice, 18(4), 63-77.

Carr, J. C., \& Sequeira, J. M. (2007). Prior family business exposure as intergenerational influence and entrepreneurial intent: A theory of planned behavior approach. Journal of Business Research, 60(10), 1090-1098.

Carsrud, A., \& Brannback, M. (2011). Entrepreneurial motivations: What do we still need to know? Journal of Small Business Management, 49(1), 9-26.

Chen, C. C., Greene, P. G., \& Crick, A. (1998). Does entrepreneurial self-efficacy distinguish entrepreneurs from managers? Journal of Business Venturing, 13(4), 295-316.

Chen, M. H. (2007). Entrepreneurial leadership and new ventures: creativity on entrepreneurial teams. Creativity and Innovation Management, 16(3), 239-249.

Collins, C. J., Hanges, P. J., \& Locke, E. A. (2004). The relationship of achievement motivation to entrepreneurial behavior: A meta-analysis. Human performance, 17(1), 95-117. 
Darmanto, S., \& Pujiarti, E. (2020). Developing student's social entrepreneurial intention. Management Science Letters, 10(5), 1103-1106.

Duong, C., Nguyen, H., Ngo, T., Nguyen, V., \& Nguyen, T. (2020). The impact of individual and environmental characteristics on students' entrepreneurial intention. Management Science Letters, 10(3), 599-608.

De Jorge-Moreno, J., Castillo, L. L., \& Triguero, M. S. (2012). The effect of business and economics education programs on students' entrepreneurial intention. European Journal of Training and Development, 36(4), 409-425.

Danhof, C. H. (1949). Observations on entrepreneurship in agriculture. Change and the entrepreneur, 20-24.

Dunn, T., \& Holtz-Eakin, D. (2000). Financial capital, human capital, and the transition to self-employment: Evidence from intergenerational links. Journal of labor economics, 18(2), 282-305.

Elston, J. A., \& Weidinger, A. (2019). Entrepreneurial intention and regional internationalization in China. Small Business Economics, 53(4), 1001-1015.

Fairlie, R. W., \& Robb, A. M. (2005). Families, human capital, and small business: evidence from the characteristics of business owners' survey. Washington, DC: Center for Economic Studies, Bureau of the Census.

Finnerty, J.F. \& Krzystofik, A.T. (1985). Barriers to small business formation. Journal of Small Business Management, 23(3), $50-58$.

Franke, N., \& Lüthje, C. (2004). Entrepreneurial intentions of business students - a benchmarking study. International Journal of Innovation and Technology Management, 1(3), 269-288.

Garo, E., Kume, V., \& Basho, S. (2015). Role Models' Effect on Students Entrepreneurial Intention. In Proceedings of the International Academic Conferences, April Rome, Italy, 14-17.

Gasse, Y., \& Tremblay, M. (2011). Entrepreneurial beliefs and intentions: a cross-cultural study of university students in seven countries. International Journal of Business, 16(4), 303.

Gelard, P., \& Saleh, K. E. (2011). Impact of some contextual factors on entrepreneurial intention of university students. African Journal of Business Management, 5(26), 10707-10717.

Giacomin, O., Janssen, F., Pruett, M., Shinnar, R. S., Llopis, F., \& Toney, B. (2011). Entrepreneurial intentions, motivations and barriers: Differences among American, Asian and European students. International Entrepreneurship and Management Journal, 7(2), 219-238.

Gomez-Mejia, L. R., \& Balkin, D. B. (1989). Effectiveness of individual and aggregate compensation strategies. Industrial Relations: A Journal of Economy and Society, 28(3), 431-445.

Gorman, G., Hanlon, D., \& King, W. (1997). Some research perspectives on entrepreneurship education, enterprise education and education for small business management: a ten-year literature review. International Small Business Journal, 15(3), 56-79.

GRIFFIN-PIERSON, S. (1990). The Competitiveness Questionnaire: a measure of two components of competitiveness. Measurement and Evaluation its Counseling and Development, 23, 108- 115.

Gubik, A., \& Farkas, S. (2016). Student Entrepreneurship in Hungary: Selected Results Based on GUESSS Survey. Entrepreneurial Business and Economics Review, 4, 123.

Guerrero, M., Rialp, J., \& Urbano, D. (2008). The impact of desirability and feasibility on entrepreneurial intentions: a structural equation model. International Entrepreneurship and Management Journal, 4(1), 35-50.

Güney, S., Oykü, Y., \& Cetin, A. (2006). Entrepreneurship and culture. Journal of Entrepreneurship and Development, 1(2), 53-77.

Gupta, V., MacMillan, I. C., \& Surie, G. (2004). Entrepreneurial leadership: developing and measuring a cross-cultural construct. Journal of business venturing, 19(2), 241-260.

Gürol, Y., \& Atsan, N. (2006). Entrepreneurial characteristics amongst university students: Some insights for entrepreneurship education and training in Turkey. Education+Training, 48(1), 25-38.

Gunnarsson, J., \& Delmar, F. (2000). How Do Self-Employed Parents of Nascent Entrepreneurs Contribute?. University of Illinois at Urbana-Champaign's Academy for Entrepreneurial Leadership Historical Research Reference in Entrepreneurship.

Hair, J. F., Anderson, R. E., Tatham, R. L., \& Black, W. (2010). Multivariate data analysis (7th Ed.). Upper Saddle River, NJ: Prentice Hall.

Helmreich, R. L., \& Spence, J. T. (1978). The Work and Family Orientation Questionnaire: An objective instrument to assess components of achievement motivation and attitudes toward family and career. American Psycholog Ass., Journal of Supply Abstract Service, 8(35).

Henseler, J., Ringle, C. M., \& Sarstedt, M. (2015). A new criterion for assessing discriminant validity in variance-based structural equation modeling. Journal of the academy of marketing science, 43(1), 115-135.

Hisrich, R. D., Peters, P. M., \& Shepard, D. A. (2008). Entrepreneurship. Singapore: Mc Graw Hill International Edition.

Hmieleski, K. M., \& Baron, R. A. (2006). Optimism and environmental uncertainty: Implications for entrepreneurial performance. In W. D. Bygrave, et al. (Ed.), Frontiers of Entrepreneurship Research. Babson Park, MA: Babson College.

Hmieleski, K. M., \& Corbett, A. C. (2006). A Study of Entrepreneur Improvisational Behavior: Implications for Performance and Satisfaction. Paper presented at the Academy of Management Conference in Atlanta, GA.

Houston, J., Harris, P., McIntire, S., \& Francis, D. (2002). Revising the competitiveness index using factor analysis. Psychological Reports, 90(1), 31-34. 
Iakovleva, T. A., Kolvereid, L., Gorgievski-Duijvesteijn, M. M., \& Sørhaug, Ø. (2014). Comparison of perceived barriers to entrepreneurship in Eastern and Western European countries. International Journal of Entrepreneurship and Innovation Management, $18(2 / 3), 115-133$.

Janssen, F., Giacomin, O. \& Shinnar, R. (2013). Students' entrepreneurial optimism, overconfidence and entrepreneurial intentions. In ECSB Entrepreneurship Education Conference, Aarhus; 29-31 May.

Kautonen, T., Van Gelderen, M., \& Fink, M. (2015). Robustness of the theory of planned behavior in predicting entrepreneurial intentions and actions. Entrepreneurship theory and practice, 39(3), 655-674.

Kirkwood, J. (2007). Igniting the entrepreneurial spirit: Is the role parents play gendered? International Journal of Entrepreneurial Behavior \& Research, 13(1), 39-59.

Kock, N. (2015). Warp PLS 5.0 User Manual. Laredo, TX: Script Warp Systems.

Kock, N., \& Gaskins, L. (2014). The mediating role of voice and accountability in the relationship between Internet diffusion and government corruption in Latin America and Sub-Saharan Africa. Information Technology for Development, 20(1), 23-43.

Kock, N., \& Lynn, G.S. (2012). Lateral collinearity and misleading results in variance-based SEM: An illustration and recommendations. Journal of the Association for Information Systems, 13(7), 546-580.

Kot, S., Meyer, N., \& Broniszewska, A. (2016). A cross-country comparison of the characteristics of Polish and South African woman entrepreneurs. Economics and Sociology, 9(4), 207-221.

Knaup, A. E. (2005). Survival and longevity in the business employment dynamics data. Monthly Labor Review, $128,50$.

Krueger Jr, N. F., \& Brazeal, D. V. (1994). Entrepreneurial potential and potential entrepreneurs. Entrepreneurship Theory and Practice, 18(3), 91-104.

Krueger Jr, N. F., Reilly, M. D., \& Carsrud, A. L. (2000). Competing models of entrepreneurial intentions. Journal of business venturing, 15(5-6), 411-432.

Krueger, N. F., \& Carsrud, A. L. (1993). Entrepreneurial intentions: Applying the theory of planned behavior. Entrepreneurship Regional Development, 5(4), 315-330.

Lee, S. M., Chang, D., \& Lim, S. B. (2005). Impact of entrepreneurship education: a comparative study of the U. S. and Korea. International Entrepreneurship and Management Journal, 1(1), 27-43.

Liñán, F. (2008). Skill and Value Perceptions: How Do they Affect Entrepreneurial Intentions? International Entrepreneurship and Management Journal, 4(3), 257-272.

Liñán, F., \& Chen, Y. W. (2009). Development and cross-cultural application of a specific instrument to measure entrepreneurial intentions. Entrepreneurship Theory and Practice, 33(3), 593-617.

Liñán, F., Rodriguez-Cohard, J. C., \& Rueda-Cantuche, J. M. (2005). Factors affecting entrepreneurial intention levels. Amsterdam: Paper presented at the 45th Congress of the European Regional Science Association.

Lovallo, D., \& Kahneman, D. 2003. Delusions of success: How optimism undermines executives' decisions. Harvard Business Review, 81(7), 56-63.

Lüthje, C., \& Franke, N. (2003). The 'making' of an entrepreneur: testing a model of entrepreneurial intent among engineering students at MIT. R\&d Management, 33(2), 135-147.

Lynn, R. (1991). The secret of the miracle economy. London: SAU.

Macko, A., \& Tyszka, T. (2009). Entrepreneurship and risk-taking. Applied Psychology, 58(3), 469-487.

Mitrovic Veljkovic, S., Maric, M., Subotic, M., Dudic, B., \& Greguš, M. (2019). Family Entrepreneurship and Personal Career Preferences as the Factors of Differences in the Development of Entrepreneurial Potential of Students. Sustainability, 11(20), 5693.

Mueller, P. (2006). Entrepreneurship in the region: breeding ground for nascent entrepreneurs? Small Business Economics, $27(1), 41-58$.

Norton, W., \& Moore, W. (2006). The influence of entrepreneurial risk assessment on venture launch or growth decisions. Small Business Economics, 26(3), 215-226.

Ozaralli, N., \& Rivenburgh, N. K. (2016). Entrepreneurial intention: antecedents to entrepreneurial behavior in the USA and Turkey. Journal of Global Entrepreneurship Research, 6(1), 3.

Olszewska, A. (2015). Students' perceptions and attitudes towards entrepreneurship, a cross- program and cross- cultural comparison. Journal of Social Sciences (COES\&RJ-JSS), 4(1), 597-610.

Page, S. E. (2007). The difference. How the power of diversity creates better groups, firms, schools, and societies. Princeton: Princeton University Press.

Peterman, N.E., \& Kennedy, J. (2003). Enterprise education: Influencing students' perceptions of entrepreneurship. Entrepreneurial Theory Practice. 28(2), 129-144.

Räty, H., Komulainen, K., Hytti, U., Kasanen, K., Siivonen, P., \& Kozlinska, I. (2019). University students’ perceptions of their abilities relate to their entrepreneurial intent. Journal of Applied Research in Higher Education, 11(4), 897-909.

Rauch, A., \& Frese, M. (2000). Psychological approaches to entrepreneurial success: a general model and an overview of findings. In C. L. Cooper \& I. T. Robertson (Eds.). International review of industrial and organizational psychology, 13, 101-142. Chichester: Wiley.

Scheier, M. F., \& Carver, C. S. (1992). Effects of optimism on psychological and physical well-being: Theoretical overview and empirical update. Cognitive Therapy and Research, 16(2), 201-228.

Schumpeter, J. A. (1947). The Creative Response in Economic History. Journal of Economic History, 2(2), 149-159.

Seelig, T. (2012). Ingenious: a crash course on creativity. New York: Harper Collins. 
Khan, S.A., Sharma, P.P., \& Thoudam, P. (2019). Role of attitude and entrepreneurship education towards entrepreneurial orientation among business students of Bhutan. International Journal of Recent Technology and Engineering, 8(3S), October.

Sutha, A. I., \& Sankar, P. (2016). Entrepreneurial intention and social entrepreneurship among university students in Chennai city. International Journal of Engineering Studies, 1, 93-106.

Trung, T., Xuan, H., Ngoc, H., Cong, D., \& Phuong, L. (2020). A comparative analysis of entrepreneurial intention and migration attitudes of students in Vietnam and Poland. Management Science Letters, 10(2), 479-488.

Thanh, L., Hau, D., Huyen, N., Linh, N., Doanh, D., \& Nga, N. (2020). The effects of internal and external barriers on Vietnamese students' entrepreneurial intention. Management Science Letters, 10(2), 381-390.

Thomas, A. S., \& Mueller, S. L. (2000). A case for comparative entrepreneurship: assessing the relevance of culture. Journal of International Business Studies, 31(2), 287-301.

Thompson, E. R. (2009). Individual entrepreneurial intent: Construct clarification and development of an internationally reliable metric. Entrepreneurship Theory and Practice, 33(3), 669-694.

Tolentino, L. R., Sedoglavich, V., Lu, V. N., Garcia, P. R. J. M., \& Restubog, S. L. D. (2014). The role of career adaptability in predicting entrepreneurial intentions: A moderated mediation model. Journal of Vocational Behavior, 85(3), 403-412.

Urbano, D., Aparicio, S. and Audretsch, D. (2019). Twenty-five years of research on institutions, entrepreneurship, and economic growth: what has been learned? Small Business Economics, 53(1), 21-49.

Vesper, K.H. (1983). Entrepreneurship and National Policy. Heller Institute. Massachusetts, USA.

Voorhees, C. M., Brady, M. K., Calantone, R., \& Ramirez, E. (2016). Discriminant validity testing in marketing: an analysis, causes for concern, and proposed remedies. Journal of the Academy of Marketing Science, 44(1), 119-134.

Walstad, W. B., \& Kourilsky, M. L. (1998). Entrepreneurial attitudes and knowledge of black Youth. Entrepreneurship Theory and Practice, 23(2), 5-18. https://doi.org/10.1177/104225879802300201

Zaki, J. (2012). The curious perils of seeing the other side. Scientific American Mind, 23(3), 20-21.

Zhao, H., Seibert, S. E., \& Lumpkin, G. T. (2010). The relationship of personality to entrepreneurial intentions and performance: a meta-analytic review. Journal of Management, 36(2), 381-404.

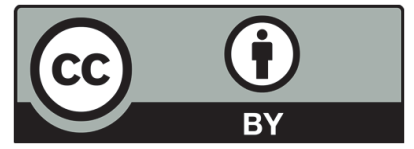

(C) 2020 by the authors; licensee Growing Science, Canada. This is an open access article distributed under the terms and conditions of the Creative Commons Attribution (CC-BY) license (http://creativecommons.org/licenses/by/4.0/). 